UDC 371.212 .3

DOI: $10.31470 / 2415-3729-2018-8-60-79$

\title{
Implementation of the Technology of Forming the Gifted Pupils' Key Competencies
}

\section{Larysa Karpova}

Doctor of Philosophy in Pedagogy (PhD), Associate Professor, Director of the Department of Science and Education of the Kharkiv Regional State Administration $\triangle$ 64, Sumska Str., Kharkiv, Ukraine, 61022, E-mail: deductionmax@gmail.com ORCID: 00000-0002-9910-5499

\section{Реалізація технологї формування ключових компетентностей обдарованих учнів}

\section{Лариса Георгіївна Карпова}

кандидат педагогічних наук, доцент, директор Департаменту науки і освіти

Харківської обласної державної адміністрації

вул. Сумська, 64, м. Харків, Україна, 61022

Дата надходження статті: 03 серпня 2018 р. Стаття прийнята до друку: 25 листопада 2018 р.

\section{Abstract}

The article theoretically substantiates the technology of forming the gifted pupils' key competences at the specially created educational and developing environment. The author focuses attention on the fact that the result of this technology implementation is the formed key competences of gifted pupils, which include: communication in the state language; main competencies in the field of natural sciences and technologies; informational and digital competence; lifelong 
learning skill; communication in foreign languages; mathematical competence; initiative and enterprise; cultural awareness and selfexpression; environmental awareness and healthy lifestyles; social and civic competencies. The article substantiates all structural components, specifies the criteria, and determines the indicators to the chosen criteria and the levels of formedness of the gifted pupils' key competences. The results of the questionnaires, tests and surveys gave grounds to state mainly the average and low levels of of formedness of the gifted pupils' key competences. On the basis of the obtained results, it was designed the technology in a specially created educational and developing environment, and the stages of its implementation were substantiated as those: organizational-diagnostic, procedural-accompanying and reflective-corrective. Some changes took place both in the experimental group EG, where the designed technology was implemented, and in the control group $\mathrm{CG}$, where the educational process was traditional. According to the motivationalvalue component - at the beginning of the experiment, most of the gifted pupils of the EG and CG had an almost equally low level of value attitude to the formation of key competencies, in particular: the high level was diagnosed at $1.62 \%(\mathrm{EG})$ and $1.87 \%(\mathrm{CG})$; the average level is $35.92 \%(\mathrm{EG})$ and $39.18 \%(\mathrm{CG})$; the low level of $62.46 \%$ (EG) and $58.95 \%$ (CG). The repeated diagnostics showed positive changes in the EG and CG groups, however, the changes were more noticeable in the EG and manifested in the rapid growth of the number of gifted pupils with the high level $-75.08 \%$ and the average $-24.92 \%$, as well as an absence of the low level pupils. In the CG, despite the fact that the proportion of gifted pupils with the high level was increased from $1.87 \%$ to $5.96 \%$ and the average level from $39.18 \%$ to $66.04 \%$, the presence of gifted pupils with the low level was still recorded $28 \%$. According to the cognitive-operational component, the percentage of EG gifted pupils who showed the high level of knowledge increased significantly from $0.65 \%$ to $78 \%$, while in the CG - from $1.12 \%$ to $24.85 \%$, and the number of gifted pupils who was reduced to the low level from $57.28 \%$ to $2.91 \%$ (EG) and from $61.94 \%$ to only $21.05 \%$. According to the evaluation-reflection component, the dynamics of formedness was manifested in the ability to carry out reflexion. Thus, in the EG, the low level decreased 
from $91.9 \%$ to $1.9 \%$, while in the CG it decreased from $89.9 \%$ to $41.83 \%$, the high level in the EG increased by $31.1 \%$, which is very noticeable in comparison with $\mathrm{CG}$, where positive changes have only occurred at $11.87 \%$. The experimental implementation of the developed technology indicates the positive results of the gifted pupils' key competencies formation in a specially created educational and developing environment.

Key words: technology, stages, formation, key competences, educational and developing environment, gifted pupils.

\section{References}

1. Antonova, O. Ye., Klymeniuk, Yu. M. (2011). Pidhotovka maibutnoho vchytelia do rozvytku intelektualnoi obdarovanosti uchniv pochatkovoi shkoly. [Preparation of a future teacher for the development of intellectual talent for elementary school pupils]. Zhytomyr : ZhDU imeni Ivana Franka [in Ukrainian].

2. Voitsekhivskyi, M. F. \& Ivashnova, S. V. (2016). Profesiina diialnist pedahoha: problemy i shliakhy vyrishennia [Professional activity of the teacher: problems and solutions]. Zasoby navchalnoi ta naukovo-doslidnoi roboty - Means of educational and research work, 46, 28-39. DOI: 10.5281/ZENODO.820779 [in Ukrainian].

3. Havrysh, I. V. \& Shcherbakova, O. O. (2014). Psykholohichna kharakterystyka uchbovoi diialnosti akademichno zdibnykh ditei $\mathrm{v}$ umovakh merytokratychnoi osvity [Psychological characteristic of educational activity of academically capable children in conditions of meritocratic education]. Teoretychni $i$ prykladni problemy psykholohii - Theoretical and applied problems of psychology, 1(33), 119-126 [in Ukrainian].

4. Hrynevych, L., Elkin, O., Kalashnikova, S., Kobernyk, I., \& Kovtunets, V. ta in. (2016). Kontseptsiia «Nova ukrainska shkola» [Concept «New Ukrainian School»]. Retrieved from http://mon.gov.ua /\%d0\%9d\%d0\%be\%d0\%b2\%d0\%b8\%d0\%bd\%d0\%b8\%202016/12/05/ konczepcziya.pdf [in Ukrainian].

5. Hrynova, V. M. \& Karpova, L. H. (2011). Proektuvannia rozvyvalnoho osvitnoho seredovyshcha dlia obdarovanykh uchniv [Designing a developing educational environment for gifted pupils]. Kharkiv : KhNPU imeni H. S. Skovorody. 
6. Hrynova, V. M. (2011). Profesiina kompetentnist uchytelia: sut, struktura, umovy formuvannia. [Fundamentals of the pedagogical designing in engineering and pedagogical education: monograph]. Kharkiv: Apostrof [in Ukrainian].

7. Zhernovnykova, O. A. (2017). Dydaktychna systema pidhotovky maibutnikh uchyteliv matematyky do proektuvanniaia navchalnoi diialnosti starshoklasnykiv.. Didactic system of training of future teachers of mathematics to designing educational activity of senior pupils]. Pedahohichnyi almanakh - Pedagogical almanac, 33, 104-110 [in Ukrainian].

8. Zhernovnykova, O. A., Nalyvaiko, O. O., Chornous, N. A. (2017). Intelectual competence: essence, components, levels of formation. Pedahohika ta psykholohiia - Pedagogy and Psychology, $58,33-42$.

9. Karpova, L. H. (2011). Sut poniattia «seredovyshche» [The essence of the concept of «environment»]. Pedahohika $i$ psykholohiia formuvannia tvorchoi osobystosti: problemy i poshuky Pedagogy and psychology of formation of a creative person: problems and searche, 16 (69), 109-117 [in Ukrainian].

10. Karpova, L. H. (2018). Obdarovanist yak psykholohopedahohichna problema [Professional competence of the teacher: essence, structure, conditions of formation]. Visnyk Cherkaskoho universytetu - Bulletin of Cherkasy University, 13, 50-56 [in Ukrainian].

11. Kasianova, O. V. (2011). Formuvannia komunikatyvnoi kompetentnosti molodshykh pidlitkiv u hromadskykh dytiachykh obiednanniakh. [Formation of communicative competence of younger teens in public children's associations]. Candidate's thesis. Kyiv: National Pedagogical Dragomanov University [in Ukrainian].

12. Kovalenko, O. A. (2010). Navchannia obdarovanykh uchniv u pochatkovii shkoli (teoretychnyi i metodychnyi aspekty). [Teaching Gifted Pupils in Elementary School (Theoretical and Methodological Aspects)]. Kharkiv : KhNPU imeni H. S. Skovorody [in Ukrainian].

13. Savchenko, O. (2014). Uprovadzhennia kompetentnisnoho pidkhodu $\mathrm{v}$ pochatkovu osvitu : zdobutky i nerozviazani problemy [Implementation of a competency approach in primary education: achievements and unresolved issues]. Ridna shkola - Native school, 4-5, 12-16 [in Ukrainian]. 
14. Tkachov, A. S. (2017). Teoriia i praktyka formuvannia kliuchovykh kompetentnostei intelektualno zdibnykh uchniv osnovnoi shkoly $\mathrm{v}$ protsesi navchannia suspilstvoznavchykh predmetiv [Theory and practice of forming the key competences of intellectually capable pupils of the main school in the process of teaching social science subjects]. Kharkiv : TOV «DISA PLIuS» [in Ukrainian].

15. Hutorskoy, A. V. (2013). Pedagogicheskie osnovaniya diagnostiki i otsenki kompetentnostnyih rezultatov obucheniya. [Pedagogical basis of diagnosis and assessment of competencebased learning outcomes]. Filsofiya $i$ metodologiya obrazovaniya Philosophy and Methodology of Education, 7, 6-15 [in Russian].

16. Grineva, V., Zhernovnykova, O., Kovalenko, O. (2018). European experience in training prospective teachecher. Lider. Elita. Suspilstvo - Leader. Elite. Society, 1, 91-99. DOI: 10.20998/26163241.2018.1.09.

17. Hoskins, B., Saisana, M. \& Villalba, C. (2015). Civic Competence of Youth in Europe : Measuring Cross National Variation Through the Creation of a Composite Indicator. Social Indicators Research, 14, 431-457.

18. Lozano, J. F., Boni, A., Peris, J., \& Hueso, A. (2012). Competencies in Higher Education : A Critical Analysis from the Capabilities Approach. Journal of Philosophy of Education, 46, 132-147.

19. Tkachov, A. (2018). The social competence formation in intellectually capable adolences pupils of tanagers. Fundamentalis scientiam, 17, 37-40.

\section{Вступ}

Нині людський ресурс перетворився в основний чинник подальшого розвитку інформаційного суспільства, що зумовлює необхідність забезпечення в загальноосвітньому закладі середньої освіти найбільш повного розкриття особистісного потенціалу кожного учня. Особливої значущості набувають проблеми організації освітнього процесу обдарованих учнів, які в майбутньому мають сформувати наукову та творчу еліту країни. При цьому в умовах реформування системи шкільної освіти на засадах компетентнісного підходу педагоги мають приділяти 
значну увагу формуванню ключових компетентностей в учнів зазначеної категорії. На важливості розв'язання цієї проблеми наголошено в таких нормативних документах, як закони України «Про освіту» (2017) і «Про загальну середню освіту» (1999, зі змінами), Національна стратегія розвитку освіти в Україні на період до 2021 року (2013), Концепція «Нова українська школа» (2016), Указ Президента України «Про заходи щодо розвитку системи виявлення та підтримки обдарованих i талановитих дітей та молоді» (2010) тощо.

Слід зазначити, що формування ключових компетентностей обдарованих учнів має відбуватись у спеціально створеному освітньо-розвивальному середовищі.

Ми спираємось на теоретико-методологічні та психологопедагогічні засади формування ключових компетентностей обдарованих учнів, розкриті дослідниками: В. Hoskins, M. Saisana, C. Villalba (2015), J. Lozano, A. Boni, J. Peris, A. Hueso (2012), О. Антонова, Ю. Клименюк (2011), І. Гавриш, О. Щербакова (2014), О. Жерновникова, О. Наливайко, Н. Чорноус (2017), О. Касьянова (2011), О. Коваленко (2010), О. Савченко (2014), А. Ткачов (2017, 2018), А. Хуторський (2013) та ін. Концептуальні підходи до проблеми створення й функціонування освітньо-розвивального середовища вивчають такі науковці, як-от: М. Войцехівський, С. Івашньова (2016), В. Гриньова, О. Коваленко (2018), О. Жерновникова (2017) та ін.

Нами розкрито суть понять «середовище» (Карпова, 2011), «освітньо-розвивальне середовище» (Гриньова, Карпова, 2011), яке вважаємо простором спільного буття, перетвореного усіма суб'єктами виховання у чинник інтегративного впливу на процес розвитку і самореалізації особистості обдарованого учня, визначено суть поняття «обдарованість» (Карпова, 2018), досліджено шляхи й умови розвитку обдарованості (Карпова, 2018), виявлено особливості створення освітнього простору школи інтернату для обдарованих дітей з позиції формування компетентності педагога (2019). Визначено ступінь сформованості, форму і широту проявів різних видів обдарованості; особливості вікового розвитку (Карпова, 2018), схарактеризовано структуру дослідницької компетентності вчителя (Карпова, 2019) та виокремлено специфіку 
дослідницької компетентності вчителя НУШ, який працює 3 обдарованими учнями (Карпова, 2019).

Мета статті - теоретично обгрунтувати та експериментально перевірити технологію формування ключових компетентностей обдарованих учнів.

\section{Матеріал і методи дослідження}

Для досягнення поставленої мети було використано теоретичні (аналіз наукової літератури 3 досліджуваної проблематики, синтез, порівняння, оцінка й узагальнення зібраних фактів) та емпіричні (спостереження, опитування, тестування, анкетування) методи дослідження.

\section{Результати та їх обговорення}

У науковій літературі (А. Ткачов (2017), О. Савченко (2014), А. Хуторський (2013) та ін.) та освітніх документах визначаються різні набори ключових компетентностей, якими мають оволодіти учні під час здобуття загальної середньої освіти. Відповідні напрацювання щодо сутності й складу ключових компетентностей для загальної середньої освіти були враховані під час проведення дослідження, проте за базову в роботі визначено сукупність ключових компетентностей, окреслену в Концепції «Нова українська школа» (2016), серед яких: спілкування державною (і рідною в разі відмінності) мовою; основні компетентності в галузі природничих наук i технологій; інформаційно-цифрова компетентність; уміння вчитися впродовж життя; спілкування іноземними мовами; математична компетентність; ініціативність і підприємливість; обізнаність та самовираження у сфері культури; екологічна грамотність і здоровий спосіб життя; соціальна та громадянська компетентності. У процесі проведеного дослідження визначено, що створення спеціального освітньорозвивального середовища сприяє сформованості в обдарованих учнів ключових компетентностей. Проведений науковий аналіз суті поняття «освітньо-розвивальне середовище» надає підстави стверджувати наступне: сприятливе освітньо-розвивальне середовище $\epsilon$ лише можливістю, але не гарантією розвитку обдарованості особистості; масове суспільство $є$ середовищем, яке не сприяє розвиткові обдарованості; значна частина вчителів декларує готовність підтримувати й розвивати обдарованих учнів, 
але насправді заперечує поведінкові прояви обдарованості та відкидає обдарованих учнів; ідентифікація дитини як обдарованої нерідко створює занадто високі очікування в оточуючих, що стають додатковим стресовим чинником для учнів (Гриньова, Карпова, 2011).

На основі вищезазначеного було виокремлено компоненти й рівні сформованості ключових компетентностей, розроблено діагностичні карти i діагностичний матеріал. Прояв ключових компетентностей обдарованих учнів здійснювався лише в освітній діяльності (спостереження, фіксація та оцінювання вміння виконати ту чи іншу дію). Таким чином, у процесі проведення діагностики нами було виявлено рівні сформованості ключових компетентностей (високий, середній, низький).

Кожна 3 визначених ключових компетентностей складається 3 мотиваційно-ціннісного (мотивація та ціннісне ставлення обдарованих учнів до формування ключових компетентностей; наявність широких пізнавальних інтересів, бажання i досвід самостійного набуття нових знань, виконання завдань без додаткового стимулювання; наявність інтересів, потреби i готовності до набуття знань і умінь працювати 3 інформацією, використовувати інформаційні технологіï); когнітивноопераційного (теоретичні знання 3 предмета; знання способів i прийомів пізнавальної діяльності; актуалізація та застосування необхідних знань, умінь і способів діяльності в стандартних i нестандартних ситуаціях у контексті розв'язання того або іншого завдання, проблеми; здатність не лише відтворювати відомі методи, способи вирішення, а й уміння самостійно знаходити нові розв'язки в стандартних і нестандартних ситуаціях; здатність ставити запитання по суті проблеми i відшукувати на них відповідь, визначати напрями пошуку, усувати i виправляти допущені помилки; вміння виконувати проектну, дослідницьку діяльність; вміння демонструвати результати своєї роботи 3 використанням комп'ютерних засобів і технологій; вміння самостійно шукати, отримувати, систематизувати, аналізувати i відбирати, перетворювати, зберігати i передавати інформацію адекватної завданню; володіння навичками роботи 3 різними джерелами інформації; вміння орієнтуватися в інформаційних 
потоках, виділяти 3 них головне і необхідне, критично ставиться, визначати ступінь достовірності інформації) i особистіснорефлексійного компонентів (наявність визначених ціннісних орієнтацій, самостійність, вольові якості; відповідальність, пізнавальна активність, творчість, рефлексія).

3 урахуванням теоретичних аспектів дослідження визначено критерії, за якими оцінювалася сформованість кожного компоненту: мотиваційно-ціннісний компонент - за мотивацією, інтересом та ціннісним ставленням обдарованих учнів до формування ключових компетентностей; когнітивноопераційний - за знаннями 3 предмета; відповідними вміннями, володінням операційними способами діяльності, готовністю до здійснення цієї діяльності; особистісно-рефлексійний - за наявністю визначених ціннісних орієнтацій, самостійністю, вольовими якостями; здатністю здійснювати рефлексію. У процесі дослідження нами встановлені рівні сформованості ключових компетентностей обдарованих учнів: високий, середній, низький.

На констатувальному етапі педагогічного експерименту за допомогою комплексу вимірювальних процедур визначено рівень сформованості ключових компетентностей обдарованих учнів.

Сформованість мотиваційно-ціннісного компоненту ключових компетентностей перевірялася в процесі проведення бесід та анкетування, а також упровадження методики «Діагностика цінностей та мотивів навчальної діяльності», де обдарованим учням пропонувалося оцінити значущість запропонованих мотивів (за 3-х бальною шкалою) та визначити, для чого обдарованому учню необхідно формувати ключові компетентності:

1. Розширити свої знання.

2. Заповнити вільний час.

3. Розважитись, отримати задоволення.

4. Завоювати авторитет у друзів, вчителів, батьків.

5. Поділитись своїми знаннями 3 іншими.

6. Досягти поставлених цілей.

7. Успішно складати іспити й заліки.

8. Зайняти місце в суспільстві.

9. Самовдосконалюватися. 


\section{0. Набути досвіду для подальшого визначення 3} майбутньою професією.

Сформованість когнітивно-операційного

компоненту ключових компетентностей обдарованих учнів визначалася при проведенні тестування, де було перевірено рівень знань, умінь та навичок дітей. Також було застосовано: психологічний тест соціального інтелекту (Дж. Гілфорд) - для оцінки загального рівня розвитку соціального інтелекту i здатностей розуміти поведінку людей; методику діагностики емоційного інтелекту (оцінка здатності обдарованого учня розуміти ставлення особистості, що репрезентується в емоціях, і керувати емоційною сферою на основі прийняття рішень); методику визначення когнітивно-діяльнісного стилю (визначення різних стильових особливостей сприйняття, мислення, спілкування та інших когнітивних процесів); методику визначення організаторських i комунікативних якостей, а також визначення рівня лідерського потенціалу.

Сформованість особистісно-рефлексійного компоненту ключових компетентностей обдарованих учнів перевірялася у процесі створення проектів при вивченні навчальних предметів, де було перевірено уміння використовувати набуті знання та навички в нових та нестандартних ситуаціях, здійснювати рефлексійний аналіз та корекцію власної діяльності.

Результати проведеного анкетування, тестування та опитування дали підстави констатувати переважно середній та низький рівні сформованості ключових компетентностей обдарованих учнів (див. табл. 1-3).

Слід також зазначити, що нами було проведено анкетування серед учителів, які працюють 3 обдарованими учнями (96 педагогів 33СО м. Харкова). Результати опитування надали підстави констатувати наступне: відсутність ініціативи та реальної участі 3 боку усього педагогічного колективу у роботі з обдарованими учнями (75\%); незацікавленість у роботі 3 обдарованими учнями частини педагогів (81\%); відсутність у частини педагогів необхідної теоретичної підготовки до роботи 3 обдарованими учнями (95\%).

На основі отриманих результатів було розроблено технологію формування ключових компетентностей обдарованих учнів у 
спеціально створеному освітньо-розвивальному середовищі, яка мала реалізуватися на таких етапах: організаційно-діагностичний, процесуально-супровідний та рефлексійно-коригувальний.

Реалізація організаційно-діагностичного

emany передбачала урахування особистісних інтересів обдарованих дітей, які можуть не збігатись 3 напрямом спеціалізації у навчанні, тому створювалися комплекси відповідних гуртків, тим самим згармонізувавши навчальні та особистісні інтереси учнів. Діяльність усього була спрямована на забезпечення комфортного перебування обдарованого учня у новому для нього середовищі. Цьому значною мірою повинна сприяти просторова організація приміщень закладу освіти, його матеріально-технічне забезпечення, доступ до інформаційних ресурсів у вигляді Інтернету тощо. На даному етапі були зроблені перші заміри сформованості ключових компетентностей в обдарованих дітей.

Реалізація процесуально-супровідного етапy передбачала створення умов для опанування учнем як програмним матеріалом, так і метапредметним, що враховував нахили особистості через побудову індивідуальних освітніх траєкторій його розвитку за напрямами спеціалізації. Ставилося завдання забезпечити учнів інформаційними ресурсами для якісного оволодіння освітнім контентом завдяки широкому використанню мережі Інтернет, бібліотечного фонду, консультацій з викладачами закладів вищої освіти. На даному етапі значну увагу приділяли співпраці обдарованих дітей 3 педагогічним колективом та студентами закладів вищої освіти, де школярі повинні на регулярній основі поглиблювати профільну підготовку.

Було започатковано комплексну роботу учнів за визначеним для них напрямом спеціалізації на базі закладів вищої освіти. При цьому особливу увагу приділяли організації науководослідної роботи учнів для їхньої подальшої участі у різних конкурсних програмах, у роботі школи Малої академії наук тощо. Створювалися учнівські наукові товариства для централізації цієї роботи з метою збереження унікальності здібностей учня.

Реалізація рефлексійно-коригувального етапу була націлена на створення умов для урахування потреб та інтересів учня як представника соціуму. При цьому брали до уваги проблеми 
обдарованої особистості у середовищі 33СО, які можуть виникати у спілкуванні 3 однокласниками, порушенні взаємодії 3 учителями, непорозумінні 3 батьками, проявах девіантної поведінки тощо. На даному етапі відбувалося творче застосування знань та вдосконалення вмінь обдарованих дітей, набутих на попередніх етапах, розвиток творчого мислення й формування стійкої рефлексійної позиції.

У педагогічному експерименті (2014-2018 н.р.) взяло участь 577 обдарованих учнів, 3 яких було створено експериментальну групу (ЕГ 309 учнів Комунального закладу «Обласна спеціалізована школа-інтернат II-III ступенів «Обдарованість» Харківської обласної ради») та контрольну групу (КГ 268 учнів Харківських гімназій № 107, № 116, № 169).

В експериментальній групі ЕГ, де було впроваджено розроблену технологію, та в контрольній групі КГ, де освітній процес проходив традиційно, відбулися певні зрушення (див. табл. 1-3).

Таблиия 1

\section{Результати контрольного етапу експериментальної перевірки сформованості мотиваціно-ціннісного компоненту ключових компетентностей обдарованих учнів}

\begin{tabular}{|r|c|c|c|c|c|c|}
\hline \multirow{2}{*}{ Рівні } & \multicolumn{3}{|c|}{ ЕГ (309 осіб) } & \multicolumn{3}{|c|}{ КГ (268 осіб) } \\
\cline { 2 - 7 } & До експ. & Після експ. & Приріст & Конст. зріз & Контр. зріз & Приріст \\
\hline 1. Мотивація обдарованих учнів до формування ключових компетентностей \\
\hline високий & $1,62 / 5$ & $75,08 / 232$ & $+73,46$ & $1,87 / 5$ & $15,96 / 43$ & $+14,09$ \\
\hline середній & $35,92 / 111$ & $24,92 / 77$ & -11 & $39,18 / 105$ & $66,04 / 177$ & $+26,86$ \\
\hline низький & $62,46 / 193$ & - & $-62,46$ & $58,95 / 158$ & $18 / 48$ & $-40,95$ \\
\hline \multicolumn{7}{|c|}{ 2. Ціннісне ставлення обдарованих учнів до формування ключових } \\
\hline вомпетентностей \\
\hline високий & $2,91 / 9$ & $64,08 / 198$ & $+61,17$ & $5,97 / 16$ & $25 / 67$ & $+19,03$ \\
\hline середній & $32,04 / 99$ & $35,92 / 111$ & $+3,88$ & $33,96 / 91$ & $47 / 126$ & $+13,04$ \\
\hline низький & $65,05 / 201$ & - & $-65,05$ & $60,07 / 161$ & $28 / 75$ & $-32,07$ \\
\hline 3. Інтерес у обдарованих учнів до формування ключових компетентностей \\
\hline високий & $11 / 34$ & $78,96 / 244$ & $+67,96$ & $10,07 / 27$ & $37,91 / 102$ & $+27,84$ \\
\hline середній & $42,07 / 130$ & $21,04 / 65$ & $-21,03$ & $42,16 / 113$ & $51,19 / 137$ & $+9,03$ \\
\hline низький & $46,93 / 145$ & - & $-46,93$ & $47,77 / 128$ & $10,9 / 29$ & $-36,87$ \\
\hline
\end{tabular}


На початку експерименту більшість обдарованих учнів ЕГ та КГ мали майже однаково низький рівень ціннісного ставлення до формування ключових компетентностей, зокрема: високий рівень діагностувався у 1,62\% (ЕГ) та $1,87 \%$ (КГ); середній рівень у 35,92 \% (ЕГ) та 39,18\% (КГ); низький рівень у 62,46 \% (ЕГ) та 58,95 \% (КГ). Повторна діагностика показала позитивні зміни в ЕГ та КГ групах, однак, більш помітні зміни відбулись в ЕГ, що проявилися в стрімкому зростанні кількості обдарованих учнів 3 високим рівнем $-75,08 \%$ та середнім - 24,92 \%, а також відсутності проявів низького рівня. У КГ попри те, що зросла частка обдарованих учнів з високим рівнем з 1,87\% до $15,96 \%$ та 3 середнім 3 39,18\% до 66,04\%, все одно було зафіксовано присутність обдарованих учнів 3 низьким рівнем ціннісного ставлення до формування ключових компетентностей $-18 \%$.

Змінився інтерес в обдарованих учнів до формування ключових компетентностей. Найбільш помітні зміни були позначені зниженням кількості обдарованих учнів 3 низьким рівнем в ЕГ та зростання - 3 середнім та 3 високим рівнями, зокрема: високий рівень зріс з $11 \%$ до 79,96\% в той час як в КГ - $310,07 \%$ лише до $37,91 \%$.

Вищезазначені зміни в ЕГ ми пояснюємо тим, що значно підвищилася ініціатива та зросла участь 3 боку усього педагогічного колективу в роботі 3 обдарованими учнями, вчителі проявляли повсякчас зацікавленість до своїх обдарованих вихованців, мотивували їх та підтримували на шляху формування ключових компетентностей.

Таблиия 2

\section{Результати контрольного етапу експериментальної перевірки сформованості когнітивно-операційного компоненту ключових компетентностей обдарованих учнів}

\begin{tabular}{|c|c|c|c|c|c|c|}
\hline \multirow{2}{*}{ Рівні } & \multicolumn{3}{|c|}{ ЕГ (309 осіб) } & \multicolumn{3}{c|}{ КГ (268 осіб) } \\
\cline { 2 - 7 } & До експ. & $\begin{array}{c}\text { Після } \\
\text { експ. }\end{array}$ & $\begin{array}{c}\text { При- } \\
\text { ріст }\end{array}$ & $\begin{array}{c}\text { Конст. } \\
\text { зріз }\end{array}$ & $\begin{array}{c}\text { Контр. } \\
\text { зріз }\end{array}$ & $\begin{array}{c}\text { При- } \\
\text { ріст }\end{array}$ \\
\hline \multicolumn{7}{|c|}{1. Обсяг та глибина знань } \\
\hline високий & $0,65 / 2$ & $78 / 241$ & $+77,35$ & $1,12 / 3$ & $24,85 / 67$ & $+23,73$ \\
\hline середній & $42,07 / 130$ & $19,09 / 59$ & $-22,98$ & $36,94 / 99$ & $54,1 / 145$ & $+17,16$ \\
\hline
\end{tabular}


Реалізація технологї формування ключових компетентностей обдарованих учнів

\begin{tabular}{|c|c|c|c|c|c|c|}
\hline низький & $57,28 / 177$ & $2,91 / 9$ & $-54,37$ & $61,94 / 166$ & $21,05 / 57$ & $-40,89$ \\
\hline 2. Вміння, володіння операційними способами діяльності \\
\hline високий & - & $32,04 / 99$ & $+32,04$ & - & $17,08 / 46$ & $+17,08$ \\
\hline середній & $26,86 / 83$ & $64,08 / 198$ & $+37,22$ & $23,89 / 64$ & $47,77 / 128$ & $+23,88$ \\
\hline низький рівень & $73,14 / 226$ & $3,88 / 12$ & $-69,26$ & $76,11 / 204$ & $35,15 / 86$ & $-40,96$ \\
\hline \multicolumn{7}{|c|}{ ․ Готовність до здійснення навчальної діяльності } \\
\hline високий рівень & - & $31,07 / 96$ & $+31,07$ & - & $14,46 / 39$ & $+14,46$ \\
\hline середній рівень & $13,9 / 43$ & $67 / 207$ & $+53,1$ & $22 / 59$ & $47,77 / 128$ & $+25,77$ \\
\hline низький рівень & $86,1 / 266$ & $1,93 / 6$ & $-84,17$ & $78 / 209$ & $37,77 / 101$ & $-40,23$ \\
\hline
\end{tabular}

В ЕГ відсоток обдарованих учнів, які показали притаманний високому рівню обсяг та глибину знань, значно виріс: від 0,65\% до $78 \%$, тоді як у КГ - $31,12 \%$ до 24,85\%, а кількість обдарованих учнів, у яких було діагностовано низький рівень, зменшилася 3 57,28\% до 2,91 \% (ЕГ) та 3 61,94 \% лише до $21,05 \%$ у КГ. Значні зміни було зафіксовано і за показниками вміння, володіння операційними способами діяльності та готовності до здійснення навчальної діяльності: у ЕГ зменшився відсоток обдарованих учнів, які продемонстрували низький рівень за третім показником - $386,1 \%$ до $1,93 \%$, а за другим показником - 373,14 \% до 3,88 \%; за третім показником помітно зріс відсоток обдарованих учнів у ЕГ: з високим рівнем - на 31 \%, а в КГ - лише на 14,46 \%. Позитивна динаміка в ЕГ пояснюється тим, що в спеціально створеному освітньо-розвивальному середовищі 3 дітьми працювали лише педагоги-професіонали, які мають високий рівень підготовки в роботі 3 обдарованими учнями. 3 такими педагогами проводилися постійнодіючі семінари вченими в цій галузі. Обдаровані учні мали можливість займатися у різних кружках, секціях, клубах, а також обирати вчителівпредметників. Навчальний заклад, в якому навчаються обдаровані діти, тісно співробітничає з різними екологічними, політичними, молодіжними, релігійними й іншими організаціями.

За оцінювально-рефлексійним компонентом сформованість проявлялась у здатності здійснювати рефлексію. Так, в ЕГ низький рівень зменшився з 91,9\% до $1,9 \%$, в той час як у КГ $389,9 \%$ до 41,83\%, а високий рівень в ЕГ зріс на $31,1 \%$, що $\epsilon$ дуже помітно в порівнянні з КГ, де позитивні зміни відбулись 
лише на 11,87 \%. Позитивна динаміка в ЕГ пояснюється тим, що створене освітньо-розвивальне середовище було цілеспрямовано орієнтовано не лише на академічну й професійну підготовку учнів, але й на розвиток їхньої функціональної грамотності (лінгвістичної, комунікативної, комп'ютерної, валеологічної тощо), а також на їхній особистісний розвиток, саморозвиток та саморефлексію.

Таблиия 3

\section{Результати контрольного етапу експериментальної перевірки сформованості особистісно-рефлексійного компоненту ключових компетентностей обдарованих учнів}

\begin{tabular}{|c|c|c|c|c|c|c|}
\hline \multirow{2}{*}{ Рівні } & \multicolumn{3}{|c|}{ ЕГ (309 осіб) } & \multicolumn{3}{c|}{ КГ (268 осіб) } \\
\cline { 2 - 7 } & До експ. & Після експ. & При-ріст & Конст. зріз & Контр. зріз & При-ріст \\
\hline \multicolumn{7}{|c|}{1. Здатність здійснювати рефлексію } \\
\hline високий & - & $31,1 / 96$ & $+31,1$ & - & $11,87 / 32$ & $+11,87$ \\
\hline середній & $8,1 / 25$ & $67 / 207$ & $+58,9$ & $10,1 / 27$ & $46,3 / 124$ & $+36,2$ \\
\hline низький & $91,9 / 284$ & $1,9 / 6$ & -90 & $89,9 / 241$ & $41,83 / 112$ & $-48,07$ \\
\hline 2. Наявність визначених ціннісних орієнтацій, самостійність, вольові якості \\
\hline високий & - & $50,5 / 156$ & $+50,5$ & - & $17,8 / 48$ & $+17,8$ \\
\hline середній & $18,1 / 56$ & $48,6 / 150$ & $+30,5$ & $16 / 43$ & $38,9 / 105$ & $+22,9$ \\
\hline низький & $81,9 / 253$ & $0,9 / 3$ & -81 & $84 / 225$ & $43,3 / 116$ & $-40,7$ \\
\hline
\end{tabular}

\section{Висновки}

Отже, у процесі проведення констатувального етапу педагогічного експерименту нами було застосовано комплекс діагностичних методів відповідно до кожного компонентів ключових компетентностей, у результаті чого було зроблено висновок про переважання середнього та низького рівнів сформованості в обдарованих учнів ключових компетентностей. Експериментальне впровадження розробленої технології вказує на позитивну динаміку сформованості ключових компетентностей в обдарованих учнів у спеціально створеному освітньорозвивальному середовищі. Отримання високих результатів пояснюємо тим, що, на відміну від інших дослідників, нами у процесі проведення формувального етапу педагогічного експерименту було передбачено форми організації навчально- 
пізнавальної діяльності обдарованих учнів, які інтегрували позакласну роботу на продовження освітнього процесу: предметні тижні, інтелектуальні змагання, систему конкурсів, роботу наукового товариства учнів «Конкордіа». Проведена робота дала свої результати, оскільки учні школи-інтернату «Обдарованість» були одними 3 кращих в Україні за результатами участі в інтерактивних учнівських конкурсах i турнірах «Кенгуру», «Левеня», «Бобер», «Соняшник», «Геліантус», Малої академії наук та інших.

Отже, маємо всі підстави стверджувати, що розроблена нами та експериментально впроваджена технологія сприяє формуванню в обдарованих учнів ключових компетентностей, оскільки за рівнем сформованості всіх визначених компонентів (мотиваційноціннісний, когнітивно-операційний, особистісно-рефлексійний) в ЕГ бачимо суттєві зрушення.

Перспективи подальших розвідок убачаємо в розробці та експериментальній перевірці інноваційних форм, методів та засобів навчання обдарованих учнів у створеному освітньорозвивальному середовищі.

\section{Література}

1. Антонова О. Є., Клименюк Ю. М. Підготовка майбутнього вчителя до розвитку інтелектуальної обдарованості учнів початкової школи: монографія. Житомир : ЖДУ імені Івана Франка. 2011, 263 с.

2. Войцехівський М. Ф., Івашньова, С. В. Професійна діяльність педагога: проблеми i шляхи вирішення. Засоби навчальної та науково-дослідної роботи, 2016. Вип. 46, С. 28-39. DOI: 10.5281 /zenodo.820779.

3. Гавриш I. В., Щербакова О. О. Психологічна характеристика учбової діяльності академічно здібних дітей в умовах меритократичної освіти. Теоретичні і прикладні проблеми психологї, 2014. Випуск 1(33), С. 119-126.

4. Гриневич Л., Елькін О., Калашнікова С., Коберник I., Ковтунець В. та ін. Концепція «Нова українська школа». URL: http://mon.gov.ua/\%d0\% $9 \mathrm{~d} \% \mathrm{~d} 0 \%$ be $\% \mathrm{~d} 0 \% \mathrm{~b} 2 \% \mathrm{~d} 0 \%$ b8 $\% \mathrm{~d} 0 \%$ bd $\% \mathrm{~d} 0$ \%b8\%202016/12/05/konczepcziya.pdf (Дата звернення 10.06.2018). 
5. Гриньова В. М., Карпова, Л. Г. Проектування розвивального освітнього середовища для обдарованих учнів. Харків : ХНПУ імені Г. С. Сковороди. 2011. 112 с.

6. Гриньова В. М. Професійна компетентність учителя: суть, структура, умови формування : навч. посібник. Харків: Апостроф. 2011. 109 с.

7. Жерновникова О. А. Дидактична система підготовки майбутніх учителів математики до проектуванняя навчальної діяльності старшокласників. Педагогічний альманах, 2017. Вип. 33. С. 104-110.

8. Жерновникова О. А., Наливайко, О. О., Чорноус, Н. А. Intellectual competence: essence, components, levels of formation. Педагогіка та психологія, 2017. Вип. 58, 33-42.

9. Карпова Л. Г. Суть поняття «середовище». Педагогіка $i$ психологія формування творчої особистості: проблеми і пошуки, 2011. Вип. 16 (69), С. 109-117.

10. Карпова Л. Г. Обдарованість як психолого-педагогічна проблема. Вісник Черкаського університету, 2018. Bun. 13, С. 50-56. 11. Касьянова О. В. Формування комунікативної компетентності молодших підлітків у громадських дитячих об'єднаннях: дис. ... канд. пед. наук: 13.00.07. Національний педагогічний університет імені М. Драгоманова. 2011.

12. Коваленко О. А. Навчання обдарованих учнів у початковій школі (теоретичний і методичний аспекти): монографія. Харків : ХНПУ імені Г. С. Сковороди, 2010. 326 с.

13. Савченко О. Упровадження компетентнісного підходу в початкову освіту : здобутки і нерозв'язані проблеми. Рідна школа, 2014. Вип. 4-5, С. 12-16.

14. Ткачов А. С. Теорія і практика формування ключових компетентностей інтелектуально здібних учнів основної школи в процесі навчання суспільствознавчих предметів: монографія. Харків : ТОВ «ДІСА ПЛЮС», 2017. 430 с.

15. Хуторской А. В. Педагогические основания диагностики и оценки компетентностных результатов обучения. Философия $u$ методология образования, 2013. Вип. 7, С. 6-15.

16. Grineva V., Zhernovnykova O., Kovalenko O. European experience in training prospective teachecher. Лiдер. Еліта. 
Суспільство, 2018. № 1, С. 91-99. DOI: 10.20998/26163241.2018.1.09.

17. Hoskins B., Saisana, M., Villalba, C. M. Civic Competence of Youth in Europe : Measuring Cross National Variation Through the Creation of a Composite Indicator. Social Indicators Research, 2015. Vol. 14, 431-457 pp.

18. Lozano J. F., Boni A., Peris J., Hueso A. Competencies in Higher Education : A Critical Analysis from the Capabilities Approach. Journal of Philosophy of Education, 2012. Vol. 46, 132-147 pp.

19. Tkachov A. The social competence formation in intellectually capable adolences pupils of tanagers. Fundamentalis scientiam, 2018. Vol. 17, 37-40 pp.

\section{Карпова Л. Г.}

\section{Реалізація технології формування ключових компетентностей обдарованих учнів}

\section{Анотація}

У статті теоретично обгрунтовано технологію формування ключових компетентностей в обдарованих учнів в спеціально створеному освітньо-розвивальному середовищі. Автором акцентовано увагу на тому, що результатом реалізації даної технології $\epsilon$ сформовані ключові компетентності обдарованих учнів, до яких віднесено: спілкування державною мовою; основні компетентності в галузі природничих наук і технологій; інформаційно-цифрова компетентність; уміння вчитися впродовж життя; спілкування іноземними мовами; математична компетентність; ініціативність і підприємливість; обізнаність та самовираження у сфері культури; екологічна грамотність i здоровий спосіб життя; соціальна та громадянська компетентності. В статті обгрунтовано всі структурні компоненти, уточнено критерії, визначено показники до обраних критеріїв i рівні сформованості ключових компетентностей обдарованих учнів. Результати проведеного анкетування, тестування та опитування дали підстави констатувати переважно середній та низький рівні 
сформованості ключових компетентностей обдарованих учнів. На основі отриманих результатів було розроблено технологію в спеціально створеному освітньо-розвивальному середовищі та обгрунтовано етапи іiі реалізації: організаційно-діагностичний, процесуально-супровідний та рефлексійно-коригувальний. В експериментальній групі ЕГ, де було впроваджено розроблену технологію, та в контрольній групі КГ, де освітній процес проходив традиційно, відбулися певні зрушення. За мотиваційноціннісним компонентом - на початку експерименту більшість обдарованих учнів ЕГ та КГ мали майже однаково низький рівень ціннісного ставлення до формування ключових компетентностей, зокрема: високий рівень діагностувався у 1,62 \% (ЕГ) та 1,87 \% (КГ); середній рівень у 35,92\% (ЕГ) та 39,18\% (КГ); низький рівень у 62,46\% (ЕГ) та 58,95\% (КГ). Повторна діагностика показала позитивні зміни в ЕГ та КГ групах, однак, більш помітні зміни відбулись в ЕГ, що проявилися в стрімкому зростанні кількості обдарованих учнів 3 високим рівнем - 75,08\% та середнім - 24,92\%, а також відсутності низького рівня. В КГ попри те, що зросла частка обдарованих учнів з високим рівнем 3 $1,87 \%$ до $15,96 \%$ та $з$ середнім $339,18 \%$ до $66,04 \%$, все одно було зафіксовано присутність обдарованих учнів 3 низьким рівнем $18 \%$. За когнітивно-операційним компонентом у ЕГ відсоток обдарованих учнів, які показали високий рівень обсягу знань значно виріс від $0,65 \%$ до $78 \%$, тоді як у КГ - $31,12 \%$ до $24,85 \%$, а кількість обдарованих учнів, яких було віднесено до низького рівня зменшилася $357,28 \%$ до 2,91\% (ЕГ) та $361,94 \%$ лише до $21,05 \%$. За оцінювально-рефлексійним компонентом динаміка сформованості проявлялася в здатності здійснювати рефлексію. Так, в ЕГ низький рівень зменшився з 91,9\% до $1,9 \%$, в той час як у КГ зменшився $3 \quad 89,9 \%$ до $41,83 \%$, а високий рівень в ЕГ зріс на $31,1 \%$, що $є$ дуже помітно в порівнянні з КГ, де позитивні зміни відбулись лише на 11,87\%. Експериментальне впровадження розробленої технології вказує на позитивні результати сформованості ключових компетентностей обдарованих учнів у спеціально створеному освітньорозвивальному середовищі.

Ключові слова: технологія, етапи, формування, ключові компетентності, освітньо-розвивальне середовище, обдаровані учні. 
Карпова Л. Г.

\section{Реализация технологии формирования ключевых компетентностей одаренных учеников}

\section{Аннотация \\ В статье теоретически обоснована технология} формирования ключевых компетентностей у одаренных учеников в специально созданном образовательно-развивающей среде. Автором акцентировано внимание на том, что результатом реализации данной технологии является сформированы ключевые компетентности одаренных учеников, к которым отнесены: общение на государственном языке; основные компетентности в области естественных наук и технологий; информационноцифровая компетентность; умение учиться на протяжении жизни; общения на иностранных языках; математическая компетентность; инициативность и предприимчивость; осведомленность и самовыражения в сфере культуры; экологическая грамотность и здоровый образ жизни; социальная и гражданская компетентности. В статье обоснована все структурные компоненты, уточнены критерии, определены показатели с выбранными критериями и уровне сформированности ключевых компетентностей одаренных учеников. Результаты проведенного анкетирования, тестирования и опроса дали основания констатировать преимущественно средний и низкий уровни сформированности ключевых компетентностей одаренных учеников. На основе полученных результатов была разработана технология в специально созданном образовательно-развивающей среде и обоснованно этапы ее реализации: организационно-диагностический, процессуальносопроводительный и рефлексивных-корректирующий.

Экспериментальное внедрение разработанной технологии указывает на положительные результаты сформированности ключевых компетентностей одаренных учащихся в специально созданном образовательно-развивающей среде.

Ключевые слова: технология, этапы, формирование, ключевые компетентности, образовательно-развивающая среда, одаренные ученики. 